\title{
MASTER
}

\section{The Status of Information for Consumers of Small Wind Energy Systems}
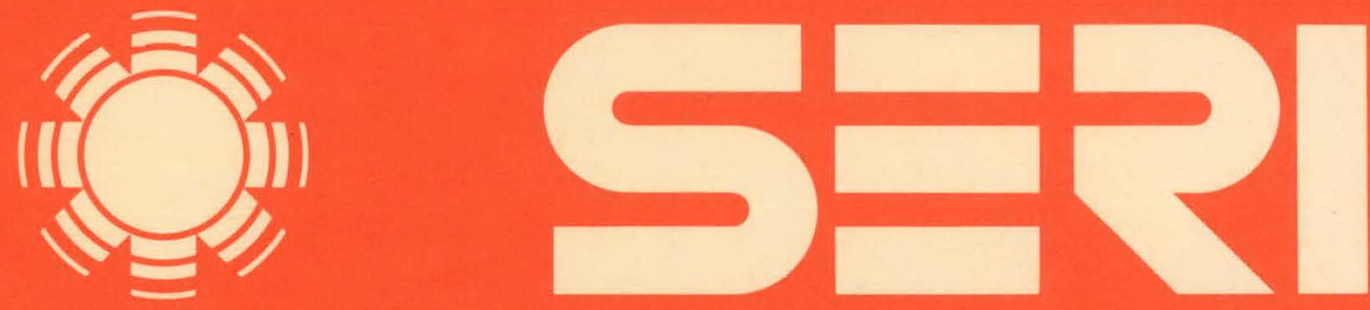

Solar Energy Research Institute

A Division of Midwest Research Institute

1536 Cole Boulevard

Golden, Colorado 80401

Operated for the

U.S. Department of Energy under Contract No. EG-77-C-01-4042

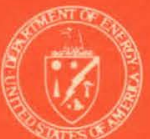




\section{DISCLAIMER}

This report was prepared as an account of work sponsored by an agency of the United States Government. Neither the United States Government nor any agency Thereof, nor any of their employees, makes any warranty, express or implied, or assumes any legal liability or responsibility for the accuracy, completeness, or usefulness of any information, apparatus, product, or process disclosed, or represents that its use would not infringe privately owned rights. Reference herein to any specific commercial product, process, or service by trade name, trademark, manufacturer, or otherwise does not necessarily constitute or imply its endorsement, recommendation, or favoring by the United States Government or any agency thereof. The views and opinions of authors expressed herein do not necessarily state or reflect those of the United States Government or any agency thereof. 


\section{DISCLAIMER}

Portions of this document may be illegible in electronic image products. Images are produced from the best available original document. 
Printed in the United States of America

Available from:

National Technical Information Service

U.S. Department of Commerce

5285 Port Royal Road

Springfield, VA 22161

rrice:

Microfiche $\$ 3.00$

Printed Copy $\$ 4.00$

\section{NOTICE}

This report was prepared as an account of work sponsored by the United States Government. Neither the United States nor the United States Department of Energy, nor any of their employees, nor any of their contractors, subcontractors, or their employees, makes any warranty, express or implied, or assumes any legal liability or responsibility for the accuracy, completeness or usefulness of any information, apparatus, product or process disclosed, or represents that its use would not infringe privately owned rights. 


\title{
THE STATUS OF INFORMATION FOR CONSUMERS OF SMALL WIND ENERGY SYSTEMS
}

\author{
PRESENTED at THE SOLAR ENERgY AND CONSERVATION \\ SYMPOSIUM - WORKSHOP \\ TECHNOLOGY - COMMERCIALIZATION - UTILIZATION \\ SPONSORED BY DOE AND THE SCHOOL OF CONTINUING STUDIES \\ UNIVERSITY OF MIAMI \\ Coral Gables, Florida \\ DECEMBER 11,1978 \\ MIAMI BEACH, FLORIDA
}

P. WEIS

\section{Solar Energy Research Institute}

1536 Cole Boulevard

Golden, Colorado 80401

A Division of Midwest Research Institute

Prepared for the

U.S. Department of Energy

Contract No. EG $\cdot 77 \cdot \mathrm{C} \cdot 01 \cdot 4042$ 
THIS PAGE

WAS INTENTIONALLY

LEFT BLANK 
Several techniques have been developed to help estimate windspeed at a site. The least expensive is firsthand observation. Several scales have been developed to aid the consumer. The Beaufort Scale in Table II relates windspeed ranges to easily recognizable motions of smoke, leaves, twigs, and trees $[2]$.

"Flagging", or the deformation of vegetation resulting from wind, can aid estimation of average annual windspeed. Figures 1 and 2 illustrate two indices which have been developed and calibrated for this purpose [1]. This sort of firsthand observation is not applicable in all areas. At best it provides a very rough estimate of average windspeed and direction.

Another source of information is wind climatology data. All sites for which airports, National Weather Service stations, or military bases have collected information have been indexed [3]. The nearest site can then be contacted directly for data. Other possible sources include: United States Forest Service, United States Soil and Conservation Service, United States Agricultural Extension Service, nuclear power plant sites, and many state and municipal sites.

Data collected nearby are often not directly transferrable to the site in question. Obstructions such as hills, trees, or buildings affect windspeed, direction, and turbulence. Much technical work has been reported on the effects of barriers on wind characteristics. A Siting Handbook for. Small Wind Energy Conversion Systems [1] provides detailed instructions, based on such work, for the consumer to calculate the effects of roughness, bulldings, shelter belts, individual trees, scattered barriers, ridges, hills, mountains, passes, saddles, gaps. gorges, valleys, canyons, basins, cliffs, mesas, and buttes.

The reliability of windspeed estimates can be somewhat improved by measuring the wind at the site itself. Limited measurements can be made and a rough correlation established with a nearby site for which there are long term data available. This procedure is described in A Siting Handbook [1] and in Wind Power for Farms, Homes and Small Industry [2].

Finally, detailed wind data can be collected at the site itself. This provides the most accurate estimates of windspeed. To collect data at the site, anamometry equipment must be purchased or rented. A 1ist of anemometry system distributors has been compiled [4]. Local telephone directories or a local wind system distributor should also be able to help locate such a service.

These procedures all provide some estimate of windspeed at the site. Of ten this is an estimate of average windspeed. Several definitions of average or mean annual windspeed are used. The consumer should be aware of the definition employed by distributors and in the literature. The most common 
usage refers to the total of windspeeds observed for the year divided by the number of observations. The time period over which the speed is average becomes important when matching wind systems with applications. An understanding of how the wind resource availability matches power demands is essential to system and storage design. Estimated windspeed data can be as general as average annual wind speed (not very useful for load matching) or as detailed as hourly or minute-by-minute windspeed.

Maximum expected return time (MERT) is the longest period of wind below the speed necessary for a wind machine to produce power. MERT is useful with average windspeed data for design of backup power or storage systems. Estimations of MERT can be made from some weather station data or from data collected at the site $[1,2]$.

Other factors 1mportant to the power harnessable in the wind can be detected and some compensations can be made at the site [1]. Turbulence can decrease harnessable power while increasing wear on the wind machine. Wind shear can damage a machine by posing unequal forces on the blades. These factors are not always present at detectable levels, which is one reason why longer term observation and data collection at the site are desirable, although without very sophisticated equipment only indications of these factors can be detected.

Potential hazards to a wind machine must be considered along with the wind resource. Thunderstorms, icing, hail, heavy snow, floods, extreme temperatures, salt spray, and blowing dust are potential hazards for which probabilities have been established. Figure 3 is a map of the United States showing the percent frequency of dusty hours based on hourly observations from weather stations. This kind of information for other hazards has been collected by various organizations. Many of these are referenced in A Siting Handbook [1].

Local topography and its wind characteristics help determine a siting strategy--tower height and location with respect to barriers. The estimates of available power in the wind at that point are then used in conjunction with the characteristics of specific machines to determine power output.

The more accurate the data collected--that is, the more sophisticated the equipment used and the longer measurements are taken at the site--the better the estimates of output power for any machine will be. Sophisticated longterm data collection can add considerably to the cost of installing wind energy conversion systems. A helpful guide to evaluating this trade-off between accuracy and expense is offered in Wind Power for Farms [2]. 
Most people considering wind power have some idea what the application will be. Electric current for lighting and appliances, resistance heating for space and process heat, and mechanical energy for water pumping are the three major uses of wind power. Any application of mechanical or electric power could potentially use a wind energy conversion system.

As discussed above, the nature of the wind resource determines available wind power. Machine size and design affect power extracted from the wind. The type of load (application) also affects output power.

Machine selection to take best advantage of the wind resource and to match the application requirements involves several steps.

A first step could be to estimate the power production of various wind machines at the site. A simplified method using percentage distributions of windspeeds over the year is presented in A Guide to Commercially Available Wind Machines $[4 \mathrm{]}$.

Several operational and performance characteristics of machines must be known to estimate power production.

1. Cut-in windspeed is the speed at which the machine begins to produce usable energy. Windspeeds below this value will produce no power.

2. Cut-out windspeed is the speed at which the machine shuts itself down for protection from damage. At wind above this speed the machine will product no power.

3. Rated power is the power generated by a machine at the specified windspeed.

4. Maximum power at a certain windspeed, for machines which have this capability, is the maximum power above rated value and the speed at which it occ.irs.

5. Power curves are graphs indicating power output at each windspeed value. When compared to estimated wind characteristics these graphs give a good indication of machine performance at that site. 
This information as well as physical characteristics, other operational and performance characteristics, and miscellaneous facts about a total of 66 wind machines from 28 manufacturers are presented in Reference 4. The information there is provided by manufacturers.

Other sources of operational and performance data on small wind energy conversion systems may soon be available. Since government is involved in the research, development, and promotion of wind energy, concern has arisen over safety as well as basic performance questions. The United States Department of Energy has begun a testing program at the Rocky Flats Plant of Rockwell International [5], and several states that have enacted tax incentives are considering test and certification programs. Programs like these increase the overall experience for a consumer to draw upon. At present many of the performance characteristics available are calculated assuming certain machine efficiencies. Testing programs will provide additional information on actual operation.

Another necessary step in machine selection is estimating the energy requirements for the application intended. If total electric or natural gas requirements are to be replaced, the history of utility bills can be used to calculate load requirements. Often, however, only part of the load will be replaced or a new process will be powered by energy from the wind. In such cases an estimation of energy demand must be made.

The calculations mentioned here are described in detail in wind Power for Farms [2]. For electrical applications the power drawn by each appliance and the hours per month they will operate must be determined. Several groups publish figures on wattage drawn by electrical appliances [6].

Hourly demand levels should be estimated, if possible, in order to determine peak demand periods. If these peak periods do not coincide with periods of good wind, adjustments in use schedule, storage or back-up power will need to be made.

Mechanica1 load, usually expressed in horsepower, may be on the data plate of a device to be driven. For pumping water, the calculation requires consideration of lift heights, pipe diameters, fittings, and pumping capacity. Careful calculation of water requirements must be matched to the wind power outputs of machines to determine required storage.

Another step in machine selection is to compare the load profile (hourly, daily, weekly, or monthly) with the estimated output power of various machines. A Siting Handbook [1] and Wind Power for Farms [2] discuss machine selection and storage design decisions. Local manufacturers or distributors of wind energy conversion systems can be of help at this stage in particular. An Index of Manufacturers, Researchers and Distributors Currently Involved in the Development of Wind Energy Conversion Systems [7] has been prepared by the 
American Wind Energy Association and can be used to locate sellers of wind machines.

Additional information for applying wind energy is being developed by the United States Department of Agriculture's wind energy conversion system applications and testing effort. This program is testing and evaluating small machines in actual farm and rural applications to determine operational requirements of those applications [8].

WHAT WILL BE THE COST OF ENERGY FROM THE WIND?

There are several aspects to the cost of wind energy besides first cost. Although information on costs or techniques for estimation of cost are limited, some work has been done. Several ongoing projects will help to improve information in this area.

1. Total Installed Cost. This usually includes all components necessary to provide normal operation of the system in the application selected. Components could include: wind turbine; tower; foundation; guy wires; storage batteries; storage tank; pumps; housing for equipment; wires; and all installation costs such as delivery, plumbing, and electrical work. Any extra expense incurred to adapt a backup system must also be included.

Since each potential wind energy conversion system is designed, to a large degree, for a specific wind site and application, actual prices for total installation should be requested from manufacturers, dealers, or distributors of systems. A Guide [4] provides names and addresses for contacting sellers of those machines that appear to meet site and application requirements.

2. Expected System Life. This is one area where there is very little information to aid the consumer [2]. 'System life depends on the design life of the machine and hazards of the site, as well as proper installation and maintenance. The test facility operating at Rocky Flats [5] and any future testing done by states or other organizations will help with system life estimates. Often machines are assumed to have a design life of 30 years.

3. Usable Energy Yield. This is the total energy used directly and from storage. It can be calculated after resource assessment and applications analyses have been completed [1,2]. Energy that must be "dumped" does not offset costs and is not considered here. In some areas it is possible to eell extra electricity produced to the local utility and buy back power during slack wind periods. In this case energy used plus energy sold can be considered, although the value of the two to the 
system owner may differ if selling price and purchase price are not equal.

4. Annual Maintenance and Repair Costs. Again, this is an area of uncertainty for the consumer, with variables similar to those for system life estimates [2].

5. Other Costs. These can include insurance premiums, building permits, interest payments, property taxes, and sales taxes.

Some of the costs may be offset by government incentives which are now becoming available. Some of the incentives proposed are: low interest loans, property tax exemptions, accelerated depreciation, sales tax exemption, and income tax deductions or credits. Groups such as the American Wind Energy Association, local manufacturers, distributors, or state energy offices may be aware of applicable incentives.

One approach to calculating the cost of energy is to add initial cost and variable costs estimated for the life of the system and divide by total usable energy expected over the system lifetime. A 30-year design life is often used. The result is a price per kilowatt hour of energy [1, 2]. This figure can then be compared to the cost of a kilowatt hour from other energy sources at present and over the lifetime of the system. Evaluating the cost of other energy sources requires estimates of the escalation of price for conventional fuels. Guidelines for such estimates are suggested in Wind Power for Farms [2]. Estimates can be based on historic rates of utility price increases, the inflation rate, or other assumptions reasonable to the consumer.

Another approach to cost gives a rough measure for machine comparison, but is less sensitive to site and user specifics. Initial system cost, usually including only major components, is divided by rated output. In one study this calculation, for machines rated at 40 kilowatts and under, varied from $\$ 652$ to $\$ 6,125$ per kilowatt [9].

Another calculation intended to aid the decision to install a wind energy conversion system is to calculate the value to the use of energy produced and compare that to the dollars per kilowatt hour cost. This technique is particularly useful when excess power is sold back to the utility [2]. Usually such power is sold to the utility at wholesale prices and purchased from the utility for backup power at retail prices.

Personal taste is mentioned in both A Siting Handbook [1] and Wind Power for Farms [2] as a factor important in cost calculations, although no techniques have been developed to quantify it. 
Although many applications for wind energy conversion systems appear in rural or remote locations, urban and suburban sites may also be suitable for wind energy use. An owner's personal taste for a wind machine may not be shared by his neighbor or his community. Several projects have researched potential legal problems facing purchasers of wind machines [10]. Some of the legal questions identified for consumers are zoning laws, building codes, warranties, liability, and wind rights [2].

\section{CONCLUSION}

Data on wind climatology and techniques for its analysis are available to consumers. Continuing work on the effects of terrain on wind characteristics should improve the usefulness for site analysis of data collected nearby. At present, on-site collection of wind data gives good results but must be balanced against cost factors.

Guides and indices of machines and manufacturers are available to consumers. Better data on machine operational and performance characteristics are being developed through government sponsored testing programs.

Information to help consumers calculate the cost of wind energy is the least developed. Factors such as system lifetime and maintenance and repair costs have not been systematically researched. Testing and development programs will eventually improve this situation. 


\section{TABLE I}

PERCENTAGE CHANGE IN AVAILABLE POWER

WITH CHANGES IN WINDSPEEDS [2]

\begin{tabular}{cc}
$\begin{array}{c}\text { Speed } \\
\text { mph }\end{array}$ & $\begin{array}{c}\text { Percent Power Change } \\
\text { From Power at Base } \\
\text { Speed of } 10 \mathrm{mph}\end{array}$ \\
\hline 5 & -88 \\
6 & -78 \\
7 & -66 \\
8 & -41 \\
9 & -27 \\
10 & 0 Base Speed \\
11 & +33 \\
12 & +73 \\
13 & +120 \\
14 & +174 \\
15 & +238
\end{tabular}


TABLE II

BEAUFORT SCALE [2]

\begin{tabular}{|c|c|c|}
\hline & Observation & $\mathrm{mph}$ \\
\hline $\mathrm{Ca} 1 \mathrm{~m}$ & Calm. Smoke rises vertically & $0-1$ \\
\hline L1ght A1r & $\begin{array}{l}\text { Direction of wind shown by } \\
\text { smoke drift but not by wind vanes. }\end{array}$ & $1-3$ \\
\hline $\begin{array}{l}\text { Light } \\
\text { breeze }\end{array}$ & $\begin{array}{l}\text { Wind felt on face. Leaves } \\
\text { rustle. Ordinary vane moved } \\
\text { on wind. }\end{array}$ & $4-7$ \\
\hline $\begin{array}{l}\text { Gentle } \\
\text { breeze }\end{array}$ & $\begin{array}{l}\text { Leaves and small twigs in } \\
\text { constant motion. Wind extends } \\
\text { light flags. }\end{array}$ & $8-12$ \\
\hline $\begin{array}{l}\text { Moderate } \\
\text { breeze }\end{array}$ & $\begin{array}{l}\text { Raises dust and loose paper. } \\
\text { Smail branches are moved. }\end{array}$ & $13-18$ \\
\hline $\begin{array}{l}\text { Fresh } \\
\text { breeze }\end{array}$ & $\begin{array}{l}\text { Small trees in leat begin to } \\
\text { sway. Crested wavelets form } \\
\text { on inland waters. }\end{array}$ & $18-24$ \\
\hline $\begin{array}{l}\text { Strong } \\
\text { breeze }\end{array}$ & $\begin{array}{l}\text { Large branches in motion. } \\
\text { Whistling in telegraph wires. } \\
\text { Umbrellas used with difficulty. }\end{array}$ & $25-31$ \\
\hline $\begin{array}{l}\text { Near } \\
\text { gale }\end{array}$ & $\begin{array}{l}\text { Whole trees in motion. Incon- } \\
\text { venience is felt when walking } \\
\text { against the wind. }\end{array}$ & $32-38$ \\
\hline Gale & $\begin{array}{l}\text { Breaks twigs off trees. } \\
\text { Generally Impedes progress. }\end{array}$ & $39-46$ \\
\hline $\begin{array}{l}\text { Strong } \\
\text { gale }\end{array}$ & $\begin{array}{l}\text { Slight structural damage } \\
\text { occurs (chimneys \& roofs). }\end{array}$ & $47-54$ \\
\hline Storm & $\begin{array}{l}\text { Seldom experienced inland. } \\
\text { Trees uprooted. Considerable } \\
\text { etructural damage occurs. }\end{array}$ & $59-63$ \\
\hline
\end{tabular}



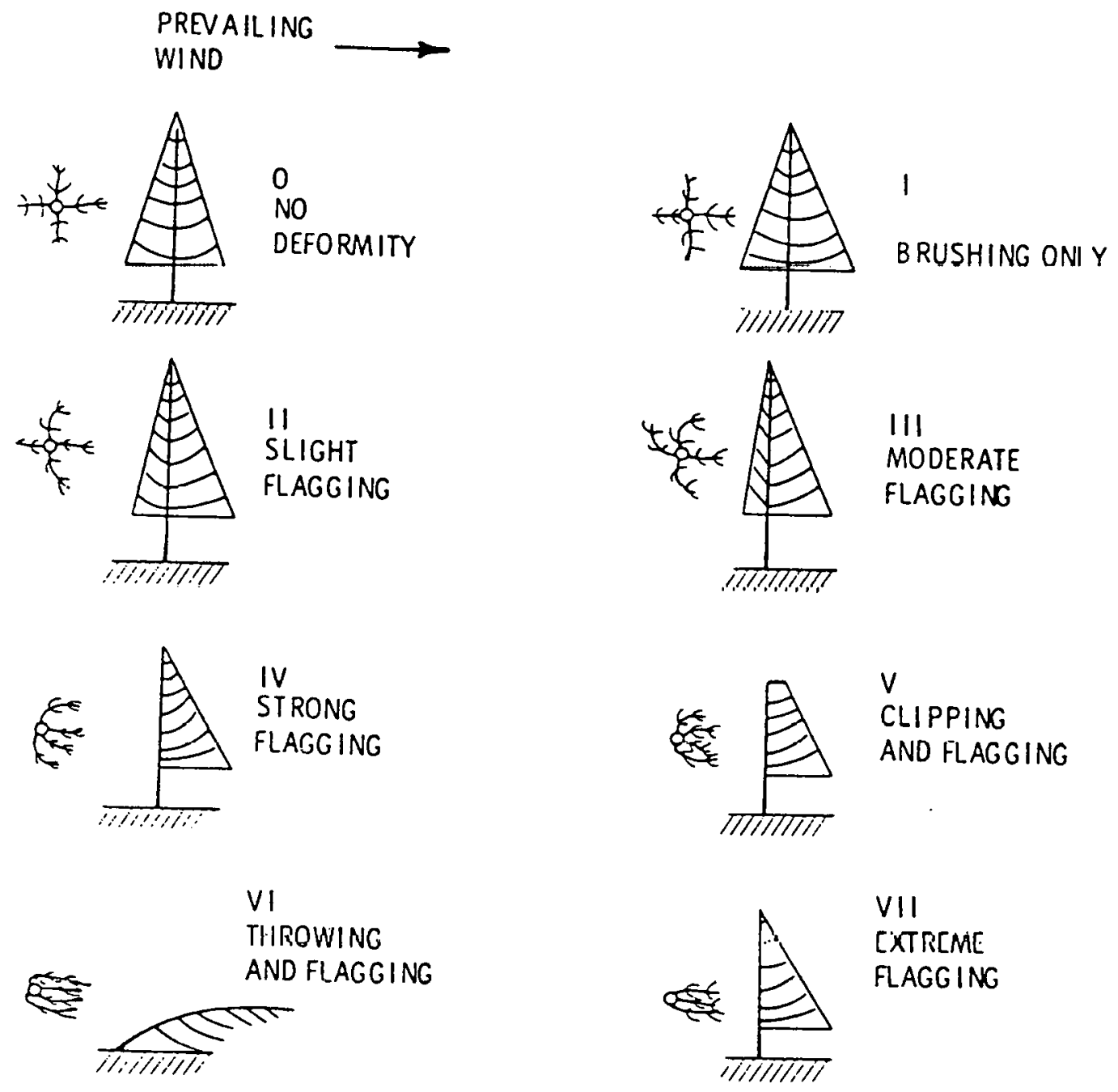

Griggs-Putnam Index

$\begin{array}{llllll}\text { (as above) } & \text { Probable Average Annual } & \text { II } & \text { III } & \text { IV } & \text { V } \\ \text { Wind Speed Range (mph) } & 6-10 & 8-12 & 11-15 & 12-19 & 13-22\end{array}$

Figure 1. Mean Annual Wind Speed Versus the Griggs-Putnam Index*

*Data prepared by E. W. Hewson, J. E. Wade, and R. W. Baker of Oregon State University, as reported in A. Siting Handbook (1). 

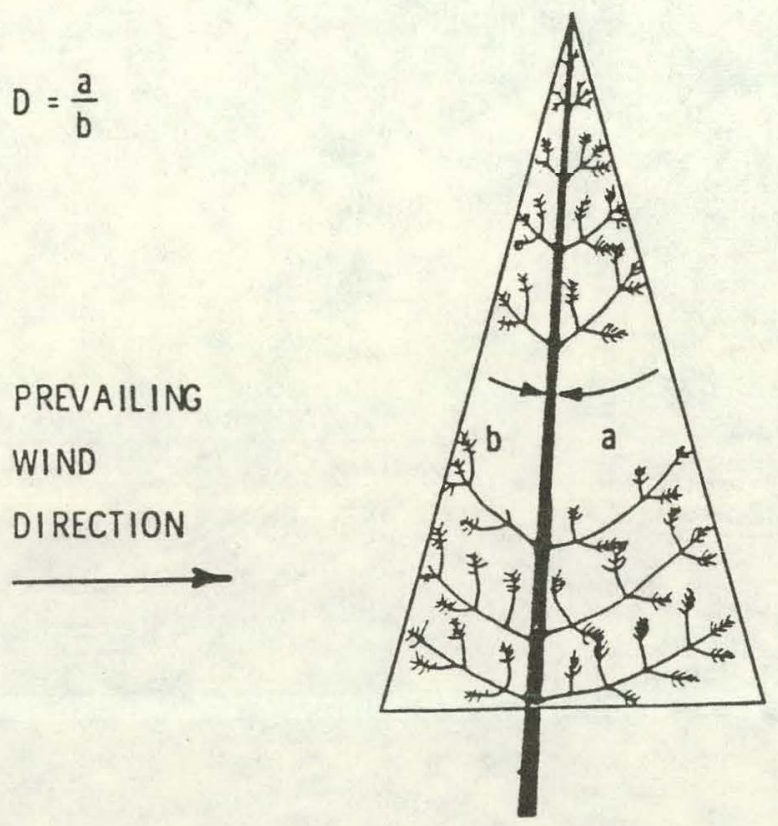

USE ONLY THE UPPER

$1 / 3$ OF THE TREE FOR

THIS MEASUREMENT

Deformation Ratio

(as above)

Probable Mean Annual

Wind Speed Range (mph)

$\begin{array}{lllllll}I & \text { II } & \text { III } & \text { IV } & \text { V } & \text { VI } & \text { VII } \\ 4-8 & 10-12 & 12-15 & 14-18 & 15-21 & 16-24\end{array}$

Figure 2. Mean Annual Wind Speed Versus the Deformation Ratio* State University, as reported in A Siting Handbook (1). 


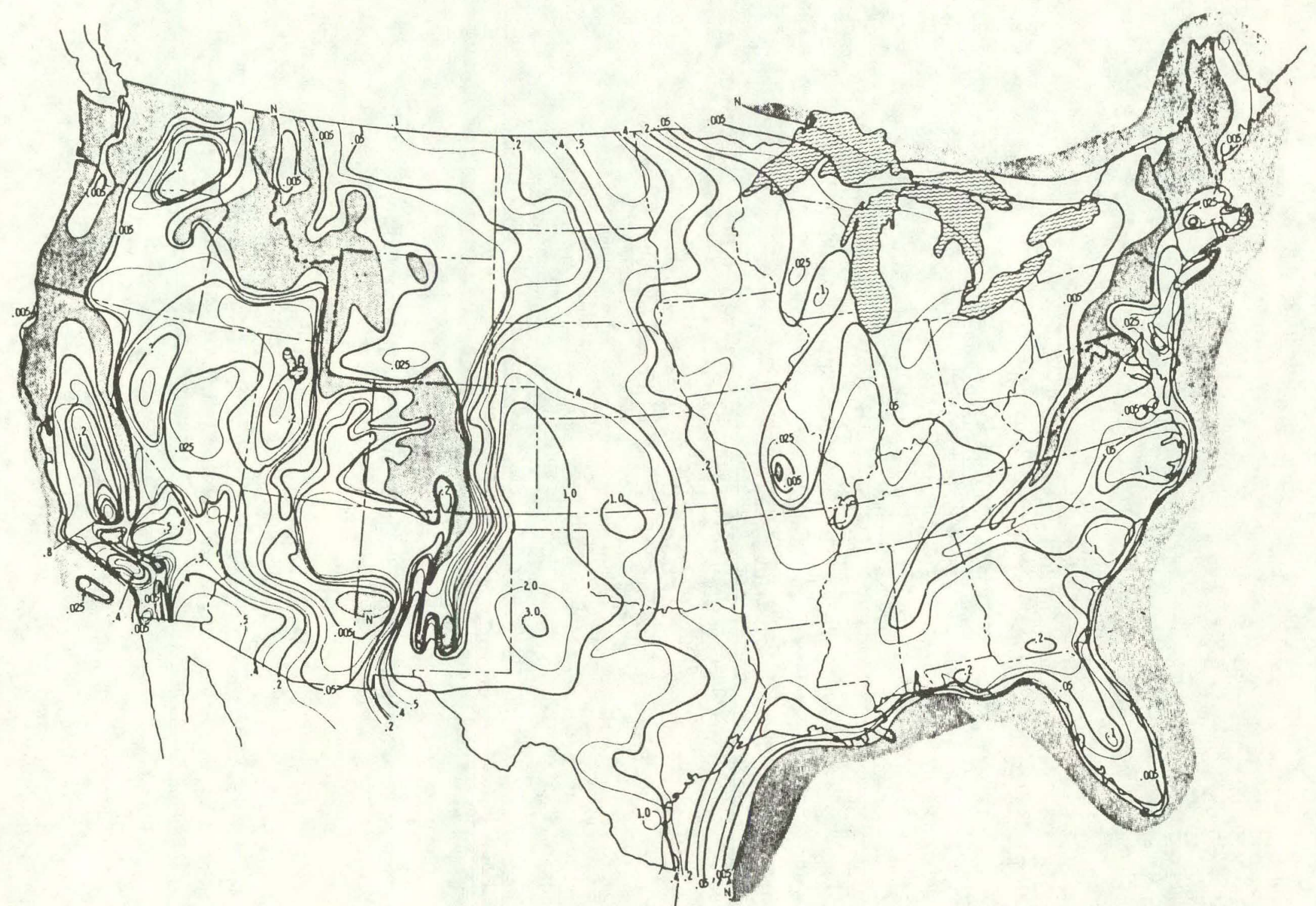

Figure 3. Annual percent Frequency of Dusty Hours. (Based on hourly observations from 343 weather observation stations that recorded dust, blowing dust and sand when prevaling visibility was less than $7 \mathrm{mi}(11 \mathrm{~km})$. Shaded areas (N) represent no observations of dust. Period of record is from 1940 to 1970 (1). 


\section{REFERENCES}

1. Wegley, H. L., M. M. Orgill and R. L. Drake, A Siting Handbook for Sma11 Wind Energy Conversion Systems, Pacific Northwest Laboratory, Battelle Memorial Institute, Richland, Washington, PNL 2521, UC-60, May 1978.

2. Park, J. and D. Schwind, Wind Power for Farms, Homes, and Small Industry, Nielsen Engineering and Research, Inc., Mountain View, Ca1ifornia, RFP 2841/1270/78/4, UC-60, September 1977.

3. Changery, M. J., W. T. Hodge and J. V. Ramsdell, Index-Summarized Wind Data, Pacific Northwest Laboratory, Battelle Memorial Institute, Richland, Washington, BNWL-2220 WIND-11, September 1977.

4. Wind Systems Program, A Guide to Commercially Available Wind Machines, Rockwel1 International, Rocky Flats Plant, Golden, Colorado, RFP-2836, April 3, 1978.

5. Wind Sytems Program, Technical and Management Support for the Development of Wind Systems for Far, Remote and Rural Use, Annual Report, Rockwell International, Rocky Flats Plant, Golden, Colorado, RFP-2721/3533/78/2, UC-60, 1977 .

6. See reports of the Association of Home Appliance Manufacturers (AHAM), Chicago, Illinois, and the Electric Edison Institute.

7. American Wind Energy Association, An Index of Manufacturers, Researchers, and Distributors Currently Involved in the Development nf Wind Energy Conversion Systems, Bristol, Indiana, DOE/RF/3533$78 / 1$, UC 60 , Febiary 1978.

8. Divone, Lou, "The Federal Wind Program," Wind Power Digest, Fal1 1978, p.40.

9. Flaim, Silvio, et al., Economic Feasibility and Market Readiness of Solar Technologies, Draft Final Report, Solar Energy Research Institute, Golden, Colorado, SERI/TR-52-055d, September 1978.

10. For example: Taubenfeld, R. F. and H. J. Taubenfeld, Barriers to the Use of Wind Energy Machines: The Present Legal/Regulatory Regime and a Preliminary Assessment of Some Legal/Political/ Societal Problems, Societal Analytics Institute, Inc., National Science Foundation grant number AER 75-18362, July 1976. 
No. of Copies

1

1

1

2

1

2

1

1

1

1
Distribution

Department of Energy:

DOE, SERI Site office

Contracting officer

Attn: Charles M. Skinner

Chicago Operations office Interim Program Division

Attn: M. E. Jackson

Division of Solar Technology office of Asst. Dir. for Administration

Attn: R. H. Annan

Office of Asst. Secretary for Conservation and Solar Applications

Attn: R. Scott

Office of Solar, Geotliermal, Electric \& Storage Programs

Attn: H. H. Marvin

Division of Energy Technology Administration

Attu: S. Hanzen

Division of Distributed Solar Technology

Office of the Director

Attn: R. San Martin

Division of Central Solar

Technology

office of the Director

Attn: H. Coleman

Division of Energy Storage

Systems

office of the Director

Attn: G. Pezdirtz

Division of Planning \& Energy

Transfer

Office of the Director

Attn: M. Adams 